\title{
Infeksi protozoa berflagela pada kura-kura indian star
}

\author{
Arief Purwo Mihardi ${ }^{1,2, *}$, Eka Dewi Wulandari ${ }^{2}$, George Marthienz Do Hage ${ }^{2}$ \\ ${ }^{1}$ Departemen Klinik Reproduksi dan Patologi, Fakultas Kedokteran Hewan, Institut Pertanian Bogor, Bogor \\ ${ }^{2}$ Praktisi Hewan Kecil, Pet+Vet Klinik, Jakarta Pusat
}

\begin{abstract}
ABSTRAK: Protozoa biasa ditemukan pada saluran pencernaan hewan reptil. Jumlah protozoa yang tinggi dapat menimbulkan masalah kesehatan pada hewan reptil seperti kura-kura. Pasien jenis kura-kura jantan dengan ras indian star datang dengan keluahan menurunnya nafsu makan serta feses yang encer dan berwarna putih. Penetapan diagnosa diperoleh dari hasil pemeriksaan fisik dan pemeriksaan laboratorium. Pemeriksaan laboratorium yang dilakukan meliputi pengamatan pada sampel feses secara natif, pengapungan dengan larutan gula jenuh serta pewarnaan sampel feses. Hasil pemeriksaan laboratorium menunjukkan bahwa kura-kura terinfeksi protozoa berflagela. Berdasarkan morfologi protozoa yang diamati, diduga termasuk ke dalam genus trichomonad. Namun perlu pemeriksaan lebih lanjut untuk memastikan jenis protozoa, karena sulit bila hanya berdasarkan pemeriksaan morfologi secara sekilas. Pengobatan yang dilakukan pada kasus kura-kura ini dengan pemberian metronidazole setiap dua hari sekali selama dua minggu. Pasca pengobatan, tidak ditemukan protozoa berflagela pada sampel feses.

Kata kunci:

kura-kura, protozoa berflagela, trichomonad
\end{abstract}

\section{- PENDAHULUAN}

Signalemen: Kura-kura ras Indian star berjenis kelamin jantan (Gambar 1). Anamnesa: Informasi yang diperoleh dari pemilik hewan, bahwa nafsu makan kura-kura mulai berkurang. Kura-kura diberi pakan pelet dan sayuran seperti daun fumak dan daun kembang sepatu. Gejala Klinis: Hasil pengamatan terhadap kura-kuran diperoleh feses yang berlendir, encer serta berwarna putih. Diagnosa dan Prognosa: Setelah dilakukan pemeriksaan natif dan pewarnaan terhadap sampel feses yang diperoleh, kura-kura didiagnosa terinfesksi protozoa. Prognosa dari kasus kurakura ini yaitu dubius-fausta.

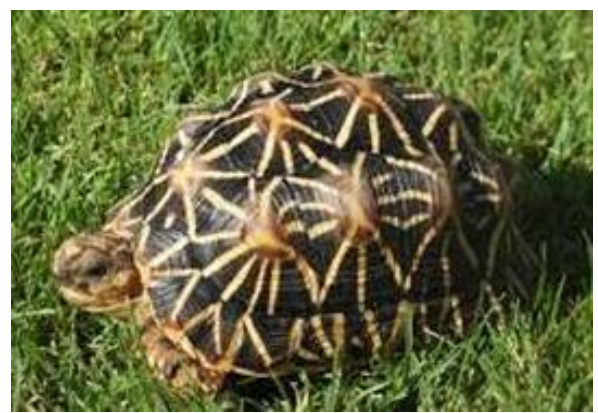

Gambar 1. Kura-kura jenis indian star yang terinfeksi protozoa

\section{- HASIL DAN PEMBAHASAN}

Berdasarkan hasil pemeriksaan fisik dan pemeriksaan laboratorium, kura-kura diduga mengalami infeksi saluran pencernaan akibat protozoa. Hasil pengamatan sampel feses dengan dilakukan pemeriksaan secara natif, metode pengapungan dengan larutan gula jenuh serta pewarnaan sampel feses diperoleh adanya protozoa dalam sampel.
Protozoa yang teramati termasuk dalam golongan protozoa berflagela. Menurut Wilkinson (2004), protozoa saluran pencernaan berflagela umumnya tidak patogen pada jenis kura-kura, namun akan sering ditemukan pada feses kurakura yang mengalami gangguan pada saluran pencernaan.

Laporan dari Scullion dan Scullion (2009), protozoa berflagela sering terdapat pada saluran pencernaan hewan reptil, namun memiliki sifat patogen yang rendah. Beberapa jenis protozoa yang sering terdapat pada reptil seperti Hexaminta, Trichomonas, Giardia, Leptomonas, dan Monocercomonas. Beberapa protozoa seperti Hexamastix, Hypotrichomonas, Tetratrichomonas, dan Tritrichomonas jarang terdapat pada reptil. Dilihat dari morfologi protozoa berflagela pada sampel feses yang diperoleh, diduga termasuk ke dalam genus trichomonad (Gambar 2). Namun deteksi jenis protozoa ini sangat sulit bila hanya berdasarkan pengamatan morfologi untuk membedakan dengan spesies protozoa lain. Secara molekuler, genetik, imunologi, klinis dan beberapa kriteria lain dapat digunakan untuk membedakan tiap spesies (Issa 2014).

Trichomonad secara umum berbentuk seperti buah pir dengan mikrotubula anterior menonjol dan berflagela 4 hingga 6 buah. Satu flagela diarahkan ke posterior dan terkadang memiliki membran undulasi. Trichomonad tidak membentuk kista (Scullion dan Scullion 2009).

\footnotetext{
Diterima: 29-10-2017 | Direvisi: 06-12-2017 | Disetujui: 04-01-2018 () 2018 CC-BY-SA. Ini adalah artikel Open Access yang didistribusikan berdasarkan ketentuan dari Creative Commons Attribution ShareAlike 4.0 International License (https://creativecommons.org/licenses/by-sa/4.0/).
} 


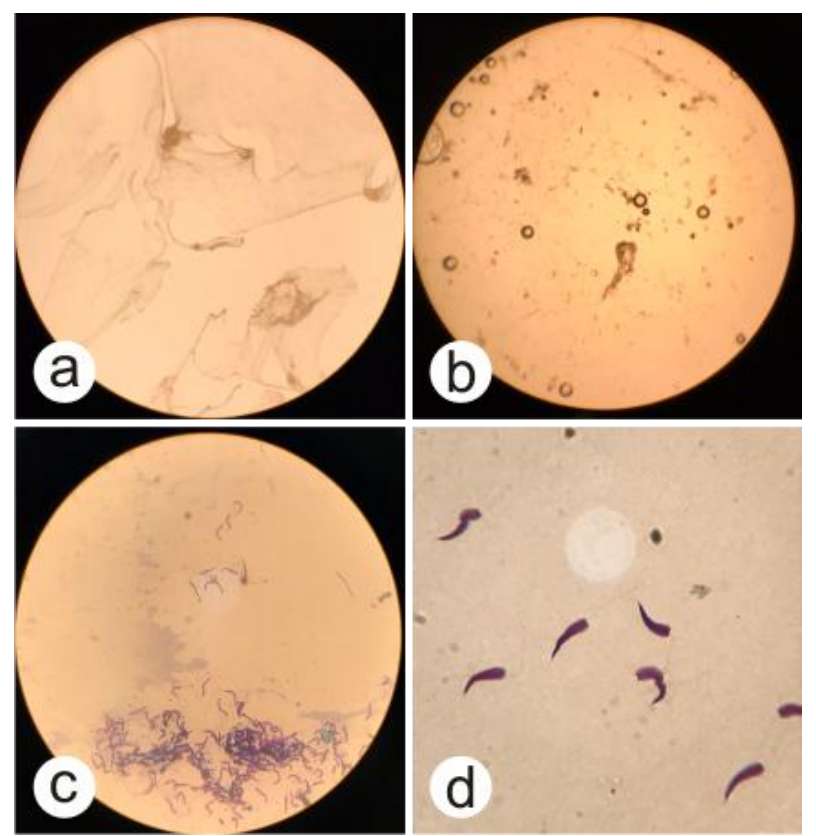

Gambar 2. Hasil pemeriksaan laboratorium pada feses kura-kura. a.) pengamatan secara natif; b.) pengamatan metode pengapungan dengan larutan gula jenuh; c.) pengamatan pewarnaan sampel feses dengan perbesaran 40 x 10; d.) pengamatan pewarnaan sampel feses dengan perbesaran $100 \times 10$

Gejala klinis yang ditunjukkan oleh kura-kura ini yaitu menurunnya nafsu makan dan feses encer, berlendir serta berwarna putih. Menurut Wilkinson (2004), gejala klinis pada infeksi parasit sangat bervariasi seperti anoreksia, diare, obstruksi saluran pencernaan, penurunan bobot badan, prolapsus anus, anemia bahkan hingga kematian.

Pengobatan yang dilakukan terhadap kasus kura-kura ini yaitu dengan pemberian metronidazole dengan dosis 20 $\mathrm{mg} / \mathrm{bobot}$ badan setiap dua hari sekali. Menurut Scullion dan Scullion (2009), jenis protozoa berflagela sensitif terhadap golongan obat imidazol. Selain itu terapi suportif termasuk menjaga sanitasi lingkungan, pemberian pakan yang baik, serta pemberian suplemen vitamin dapat mendukung persembuhan kasus infeksi akibat protozoa.

Pasca pemberian metronidazole selama dua minggu, kondisi kura-kura membaik. Hal tersebut ditunjukkan dengan tidak ditemukannya kembali protozoa berflagela pada pengamatan natif maupun pewarnaan pada sampel feses kura-kura (Gambar 3).

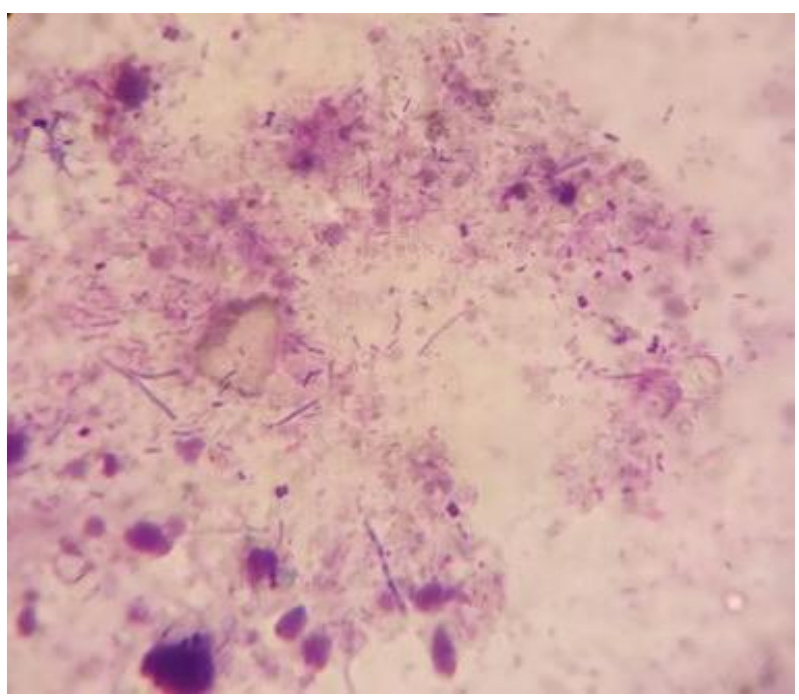

Gambar 3. Hasil pemeriksaan pewarnaan sampel feses kura-kura pasca pengobatan dengan metronidazole selama dua minggu. Pembesaran lapang padang $40 \times 10$

\section{- SIMPULAN}

Kura-kura Indian star pada kasus ini didiagnosa mengalami infeksi protozoa berflagela (genus trichomonad). Pengobatan dengan sediaan metronidazole dosis $20 \mathrm{mg} / \mathrm{kg}$ bobot badan selama 2 minggu mampu menekan protozoa.

\section{- INFORMASI PENULIS}

Penulis untuk Korespondensi

*AP: mihardi.ap@gmail.com

Divisi Penyakit Dalam, Wing 2, Level 3

Departemen Klinik, Reproduksi dan Patologi,

Fakultas Kedokteran Hewan, Institut Pertanian Bogor, Bogor

Jl. Agatis Kampus IPB Dramaga Bogor 16680

\section{- PUSTAKA ACUAN}

Issa R. 2014. Non-pathogenic protozoa (review article). International Journal of Pharmacy and Pharmaceutical Sciences. 6(3): 30-40.

Scullion FT, Scullion MG. 2009. Gastrointestinal protozoal disease in reptiles. Journal of Exotic Pet Medicine. 18(4): 266 - 278.

Wilkinson R. 2004. Clinical pathology. Di dalam: Medicine and Surgery of Tortoises and Turtles. McArthur S, Wilkinson R, Meyer J. (Eds). Blackwell : Oxford. 